Exp. Anim. 53(1), 11-19, 2004

\title{
A-type Natriuretic Peptide Level in Hypertensive Transgenic Mice
}

\author{
Hiroharu MIFUNE ${ }^{1)}$, J unichi HONDA2), Shinzo TAKAMORI ${ }^{3)}$, \\ Fumihiro SU GIYAMA ${ }^{4)}$, Ken-ichi YAGAMI ${ }^{4}$, and Syusaku SUZUKI5)
}
1)Institute of Animal Experimentation, ${ }^{2)}$ Department of 1st Internal Medicine, ${ }^{3)}$ Department of Surgery, Kurume University School of Medicine, 67 Asahi-machi, Kurume 830-0011, 4)Laboratory Animal Research Center, University of Tsukuba, Tsukuba, Ibaraki 305-8575, and ${ }^{5)}$ Laboratory of Veterinary Anatomy, Faculty of Agriculture, Kagoshima University, 1-21-24 Korimoto, Kagoshima 890-0065, Japan

\begin{abstract}
A-type (atrial) natriuretic peptide (ANP) levels in heart and plasma were examined by immunohistochemistry, electron microscopy, and radioimmunoassay $(R I A)$ in hypertensive transgenic mice (Tsukuba hypertensive mice; THM). Additionally, the ANP mRNA level in the heart was measured using real-time polymerase chain reaction (PCR) assay. The blood pressure and the ratio of heart weight to body weight in THM was significantly higher than those in the control mice (C57BL/6J). The number of ANPgranules and ANP immunoreactivity in the auricular cardiocytes were significantly lower in THM than in the control. Ultrastructurally, the ventricular cardiocytes in the THM occasionally had ANP-like granules, which were not present in the controls. Using RIA, the plasma, auricular, and ventricular ANP concentrations were significantly higher in THM than in the control, but there was no significant difference in plasma cyclic guanosine monophosphate (GMP) concentration between THM and the control. The ANP mRNA levels of the auricular and ventricular cardiocytes in the THM were siginificantly higher than those in the controls. The present study suggested that the ANP release system of the auricular cardiocytes in these transgenic mice is different from normal (control mice).
\end{abstract}

Key words: A-type natriuretic peptide, hypertension, transgenic mice, cardiocyte

\section{Introduction}

Human essential hypertension is a heterogenous disease in which blood pressure is harmfully high without overt cause. It is generally recognized as a multifactorial disease associated with etiological factors, and both genetic and environmental factors have been implicated in its etiology [21]. Several complex physiological systems affect blood pressure, including one that is mediated by the 28 -amino acid A-type (atrial) natriuretic peptide (ANP) $[13,21]$. ANP is a circulating hormone with a wide range of biological effects, including natriuresis, diuresis and vasodilation, and it plays an important role in the regulation of blood pres-

(Received 27 February 2003 / Accepted 2 September 2003)

Address corresponding: S. Suzuki, Laboratory of Veterinary Anatomy, Faculty of Agriculture, Kagoshima University, 1-21-24 Korimoto, Kagoshima 890-0065, Japan 
sure and volume homeostasis $[5,8]$. This peptide hormone is mainly produced in the cardiac atria, where it is stored within secretory granules as a large precursor (proANP), which is the major component of the granules $[5,7,27]$. Distension in the cardiac atria as seen with an increase in blood pressure represents an important stimulus for the release of ANP [17, 25].

Recently, a hypertensive transgenic mouse line, the Tsukuba hypertensive mouse (THM) has been established by cross-mating transgenic mice carrying the human renin gene [11] with mice bearing the human angiotensinogen gene [37]. As THM present higher angiotensin II and blood pressure levels than normotensive nontransgenic lines, this transgenic mouse is an animal model of human essential hypertension due to the genetically defined factors of the renin angiotensin system (RAS) [12]. RAS is one of a number of factors thought to regulate the onset of essential hypertension [10]. Recently, evidence has suggested that cardiovascular homeostasis is determined by a balance in cross-talk between the natriuretic peptide system and the angiotensin system [22]. Several investigations of ANP in cardiac tissues have been performed in the hypertensive animal model, including the spontaneously hypertensive rat (SHR) [3, 19, 29, 31], SHR-stroke prone $[2,29]$, deoxycorticosterone acetate (DOCA)-salt rat $[18,34]$, and the Dahl salt sensitive rat with sodium chloride-induced hypertension [39]. To our knowledge, no data have been published on the plasma and heart ANP levels of THM in relation to hypertension by RAS.

In order to elucidate the secretion system of the heart ANP in THM, we studied the morphological changes in the ANP-granules in atrial cardiocytes and the plasma ANP level in THM. Moreover, we examined the ANP mRNA levels in the atrial and ventricular cardiocytes to determine any change in the synthesis system of ANP in THM.

\section{Materials and Methods}

Animals: Hearts and blood were obtained from 10 males of 3-month-old THM, bred in our facility as described previously [12]. Ten males of 3-month-old non-transgenic mice, (C57BL/6J Jcl, CLEA Japan, Inc., Osaka, Japan) were used as a control. All animals were kept in automatically controlled rooms (temperature: $24 \pm 1{ }^{\circ} \mathrm{C}$; humidity: $55 \pm 5 \%$; automatic lighting:
6:00 a.m. to 8:00 p.m.) and fed with a pellet diet CE-2 (CLEA Japan, Inc., Osaka, Japan) and water ad libitum. These animals were sacrified under sodium pentobarbital anesthesia $(50 \mathrm{mg} / \mathrm{kg}$, i. p.) and the heart and blood were collected. All experiments were undertaken in accordance with the Guideline for Animal Experimentation, Kurume University.

Measurement of blood pressure (BP): $\mathrm{BP}$ was measured in all mice. The systolic BP was measured using a programmable sphygmomanometer (UR-5000; Ueda, Avancer Co., Ltd., Tokyo, Japan) using the tail-cuff method. Each unanesthetized mouse was introduced into a small holder mounted on a thermostatically controlled warming plate and maintained at $37^{\circ} \mathrm{C}$ during measurement. Four consecutive measurements of BP in one animal were taken at 15-min intervals after the equilibration period, and then the average of the four measurements was used for statistical comparisons.

Immunohistochemistry: The right auricular tissue blocks were fixed in Zamboni's solution for $24 \mathrm{hr}$ at $4^{\circ} \mathrm{C}$. After washing with $0.15 \mathrm{M}$ phosphate-buffered saline (PBS) at $\mathrm{pH} 7.3$, they were dehydrated, embedded in paraffin and sectioned at $5 \mu \mathrm{m}$ thickness. Prior to immunohistochemical staining, the deparaffinized sections were incubated in absolute methanol containing $3 \% \mathrm{H}_{2} \mathrm{O}_{2}$ for $20 \mathrm{~min}$. Immunohistochemical staining was performed according to the modified avidin-biotinperoxidase complex $(\mathrm{ABC})$ technique, described previously [26]. Following incubation in normal swine serum, sections were incubated with primary antibody overnight at $4^{\circ} \mathrm{C}$. For the ANP immunohistochemical study, rabbit antiserum against synthesized human ANP 99-126 (Code: NAW160) [32] was used as the primary antibody diluted 1: 1,000 with PBS containing $0.02 \%$ Triton X 100. As the secondary antibody, biotinylated swine anti-rabbit immunoglobulin (1: 500; DAKOPATTS A/S, Glostrup, Denmark) was used.

Electron microscopy: The right auricular and left ventricular tissues were fixed in $2 \%$ paraformaldehyde$2.5 \%$ glutaraldehyde in $0.1 \mathrm{M}$ cacodylate buffer at $\mathrm{pH}$ 7.4 and post-fixed in $1 \%$ osmium tetroxide in the same buffer. They were dehydrated in a graded series of ethanol and embedded in Epon 812. Ultrathin sections were double-stained with uranyl acetate and lead cit- 
rate, and examined with a JEM-2000 EX electron microscope.

Ultrastructural morphometry: The number of secretory granules of the right auricular cardiocytes was measured according to the modified morphometry method of Cantin et al. [6]. Thin sections were viewed on a JEM-2000 EX electron microscope at a magnification of $\times 3,000$. Ten photographs were randomly chosen from sections of the right auricular cardiocytes of each mouse in accordance with the criteria proposed by Cantin et al. [6]. The counting of ANP-granules was done on $25 \mathrm{~cm} \times 30 \mathrm{~cm}$ prints at a final magnification of $\times 14,000$, corresponding to an area of 382.7 $\mu \mathrm{m}^{2}$. The mean ( \pm S. D.) of counts was calculated from 50 photographs from 5 animals from each of the transgenic and non-transgenic mice. All values were statistically analyzed using Student's $t$ test.

Radioimmunoassay (RIA): Blood was collected from the carotid artery into a syringe containing $1 \mathrm{mg}$ of EDTA and 1,000 units of the kallikrein-inhibitor, aprotinin (Bayer, Leverkusen, Germany). The plasma was rapidly frozen and stored at $-80^{\circ} \mathrm{C}$ until measurement of the plasma ANP and the cyclic guanosine monophosphate (GMP) levels. The right auricular and left ventricular tissue samples were boiled for $5 \mathrm{~min}$ in 10 volumes of $0.1 \mathrm{M}$ acetic acid to abolish intrinsic proteolytic activity and then homogenized with a Polytron homogenizer (Kinematica AG, Littau, Lucerne, Switzerland) at 25,000 rpm for $60 \mathrm{~s}$. Each homogenate was centrifuged at $30,000 \mathrm{~g}$ for $30 \mathrm{~min}$ at $4^{\circ} \mathrm{C}$, and the supernatants were stored at $-80^{\circ} \mathrm{C}$ until RIA. The plasma and heart ANP levels were measured using an Atrial Natriuretic Factor (rat) RIA kit (Phoenix Pharmaceuticals Inc., Mountain View, CA, U.S.A.). The plasma cyclic GMP concentration was measured by RIA (Amersham International, Little Chalfont, Bucks., U.K.).

Real-time polymerase chain reaction (PCR) assay: Right auricular and left ventricular tissues were subjected to acid guanidium thiocyanate-phenol-chloroform RNA extraction, and the RNA was then stored at $20^{\circ} \mathrm{C}$ until examination. Total RNA was isolated using the RNeasy kit (Qiagen, Valencia, USA) and its concentration determined using UV spectrophotometry (DU ${ }^{\circledR}$ Series 65; Beckman, Fullerton, CA, USA). The
Table 1. Profiles of THM and C57BL/6J mice

\begin{tabular}{lcc}
\hline & C57BL/6J & THM \\
\hline Systolic blood pressure (mmHg) & $139.2 \pm 13.8$ & $186.0 \pm 18.7 * *$ \\
Heart weight/body weight (\%) & $0.482 \pm 0.09$ & $0.706 \pm 0.11^{* *}$ \\
\hline
\end{tabular}

Values are mean \pm standard deviation. **Significant difference $(\mathrm{p}<0.001)$.

quality and integrity of total RNA were assessed on $1 \%$ formaldehyde-agarose gels. First-strand cDNA was synthesized using $1 \mu \mathrm{g}$ of total RNA (DNase-treated) in a $20 \mu \mathrm{g}$ reverser transcriptase (RT) reaction mixture. The amounts of ANP and $\alpha$-actin mRNA transcripts were evaluated by real-time PCR, which was performed using the following synthetic oligonucleotides as primers: ANP, sense primer (first exon) 5' CTCCTTCTCCATCACCAAGG-3' and antisense primer (second exon) 5' -CTCTGGGCTCCAATCCTGTC-3'; $\alpha$-actin, sense primer (fifth exon) 5' AGCTGAACGTGAGATTGTGC-3', antisense primer (sixth exon) 5'-GTCGCACTTCATGATGCTGTT-3'. All real-time PCR reactions were performed in a $20 \mu \mathrm{l}$ mixture containing 1/20 volume of cDNA preparation $(2 \mu \mathrm{l}), 1 \times \mathrm{SYBR}$ Green buffer containing FastStart Taq DNA Polymerase (Roche Diagnostics GmbH, Mannheim, Germany), $2.5 \mathrm{mM} \mathrm{MgCl}_{2}, 0.2 \mu \mathrm{M}$ of each primer, and $0.2 \mathrm{mM}$ dNTP. Real-time measurements of the mRNA levels were performed using a LightCycler system (Roche Diagnostics GmbH, Mannheim, Germany). The fluorescence threshold value was calculated using the LightCyclerTM V3 system software. The PCR products were electrophoresed in agarose gel and their size was comfirmed (ANP, 417 bp; $\alpha$-actin , 250 bp) (data not shown).

\section{Results}

Blood pressure and heart weight: As shown in Table 1, THM showed hypertension with heart hypertrophy as judged from the systolic BP and the ratio of heart weight to body weight. In THM, the BP was 30 or 40 $\mathrm{mmHg}$ elevated compared to $\mathrm{C} 57 \mathrm{BL} / 6 \mathrm{~J}$ mice, indicating a significant difference between THM and the control mice $(\mathrm{p}<0.001)$.

Immunohistochemistry: ANP-immunoreactivity (IR) 

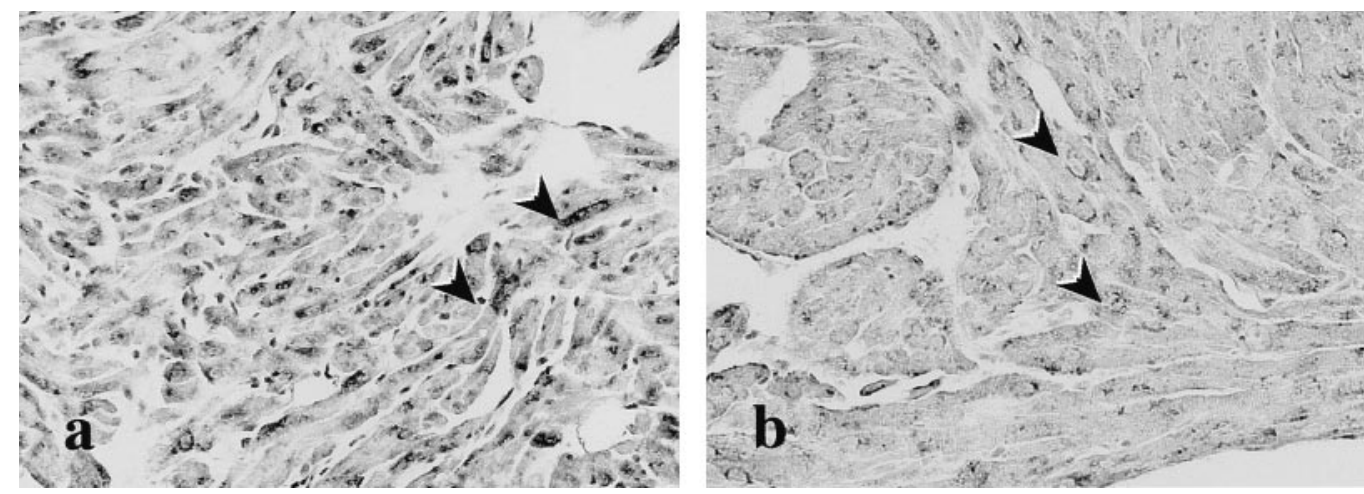

Fig. 1. Immunohistochemical staining of ANP in the right auricular cardiocytes in C57BL/6J (a) and THM (b). All magnifications are $\times 285$. ANP-immunoreactivity (IR) is located primarily in the perinuclear region of the cardiocytes in both mice (arrowheads). In C57BL/6J mouse (a), ANP-IR is stronger than in THM (b).
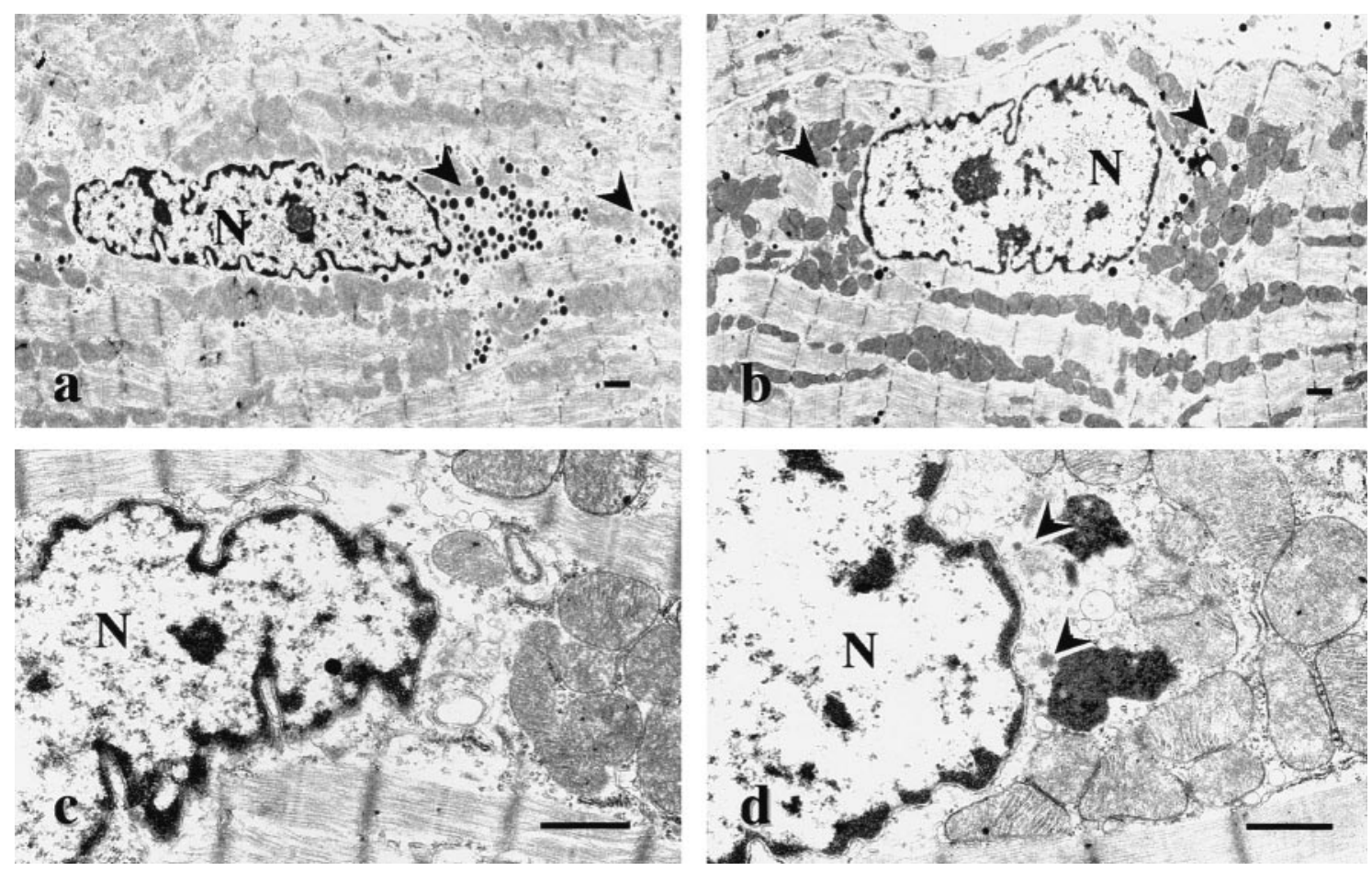

Fig. 2. Electron micrographs of the right auricular cardiocytes in C57BL/6J (a) and THM (b), and the left ventricular cardiocytes in C57BL/6J (c) and THM (d). In the auricular cardiocytes, ANP-granules (arrowheads) are variable in size and number, and are mainly located in the perinuclear region in association with the Golgi apparatus $(\mathrm{a}, \mathrm{b})$. The number of granules in THM (b) is fewer than in C57BL/6J (a). The ventricular cardiocytes in THM (d) occasionally have ANP-like granules (arrowheads), which are not observed in C57BL/6J (c). Each bar represents $1 \mu \mathrm{m}$. Nucleus (N).

was found in the right auricular cardiocytes of all mice. The ANP-IR was located primarily in the perinuclear region of the cardiocytes in both THM and C57BL/6J mice (Fig. 1). In the THM, the ANP-IR was weaker than in the controls (Fig. 1a and 1b).
Ultrastructure: In THM and C57BL/6J mice, the right auricular cardiocytes contained a centrally located nucleus, numerous mitochondria, myofibrils, a small amount of rough endoplasmic reticulum, Golgi appara- 


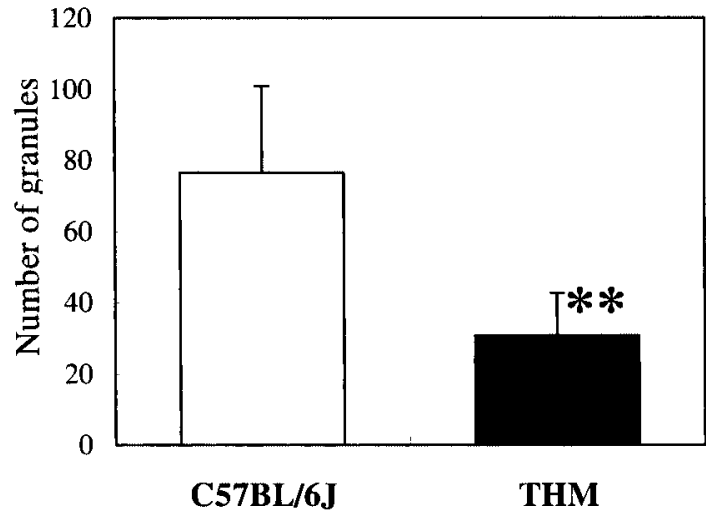

Fig. 3. Number of ANP -granules in the right auricular cardiocytes in THM $(\mathrm{n}=10)$ and C57BL/6J mice $(n=10)$. Data are mean \pm standard deviation. $* *$ Significant difference $(\mathrm{p}<0.001)$.

tus and electron-dense granules (Fig. 2a and 2b). The granules were variable in size and number, and were mainly located in the perinuclear region in association with the Golgi apparatus. The number of granules was decreased in THM compared to that in the control mice. The ventricular cardiocytes in THM occasionally had ANP-like granules, which were not observed in the controls (Fig. 2c and 2d).

Ultrastructural morphometry: The number of the granules in the right auricular cardiocytes is shown in Fig. 3. In THM, the number of granules was significantly fewer than in C57BL/6J mice $(p<0.001)$.

ANP and cGMP concentrations: By RIA, the plasma, right auricular, left ventricular ANP, and plasma cGMP concentrations are shown in Table 2. The plasma ANP concentration in THM was significantly higher than that in C57BL/6J mice ( $p<0.001)$, and the level in THM was noted to be approximately 10 -fold higher than that in the control mice. The auricular and ventricular ANP concentrations in THM were each significantly higher than those in the controls $(\mathrm{p}<0.05)$. Those levels in THM were roughly 4-times higher than those in the controls. There was no significant difference in the concentration of plasma cGMP between THM and the control mice.

Real-time PCR assay: The ANP mRNA expression indices of the auricle and ventricle in THM were significantly higher than in C57BL/6J mice $(\mathrm{p}<0.001)$. The levels in THM were roughly 4-times higher in the auricle, and approximately 40 -fold higher in the ventricle than those in the controls (Fig. 4).

\section{Discussion}

THM was produced by cross-mating transgenic mice carrying the human renin gene with mice bearing the human angiotensinogen gene. This transgenic mouse exhibits both higher angiotensin II and blood pressure levels than the normotensive nontransgenic mouse, and therefore provides an animal model of human essential hypertension due to genetically defined factors in the renin angiotensin system (RAS) [12]. THM in this study also showed hypertension with heart hypertrophy as judged from higher systolic blood pressure and a higher ratio of heart weight to body weight than those of C57BL/6J normotensive mice.

It is of great interest that: 1) the number of ANPgranules and the ANP immunoreactivity in the auricular cardiocytes in THM were significantly lower than those in normotensive mice, despite the high concentration of auricular ANP by RIA and the high level of ANP mRNA in THM; and 2) the ventricular cardiocytes had ANP-like granules only in the THM, and the ventricular ANP concentration in the THM was higher than

Table 2. ANP and cGMP levels in THM and C57BL/6J mice

\begin{tabular}{lcc}
\hline & C57BL/6J & THM \\
\hline Plasma ANP concentration $(\mathrm{pg} / \mathrm{ml})$ & $212.6 \pm 60.5$ & $1994.4 \pm 563.1^{* *}$ \\
Auricular ANP concentration $(\mu \mathrm{g} / \mathrm{g}$ wet tissue) & $57.2 \pm 9.9$ & $234.4 \pm 72.3^{*}$ \\
Ventricular ANP concentration $(\mathrm{ng} / \mathrm{g}$ wet tissue) & $25.1 \pm 8.3$ & $83.8 \pm 36.3^{*}$ \\
Plasma cGMP concentration $(\mathrm{pmol} / \mathrm{ml})$ & $6.79 \pm 1.11$ & $7.11 \pm 1.47$ \\
\hline
\end{tabular}

Values are mean \pm standard deviation. Significant difference $(* \mathrm{p}<0.05$, $* * \mathrm{p}<0.001)$. 

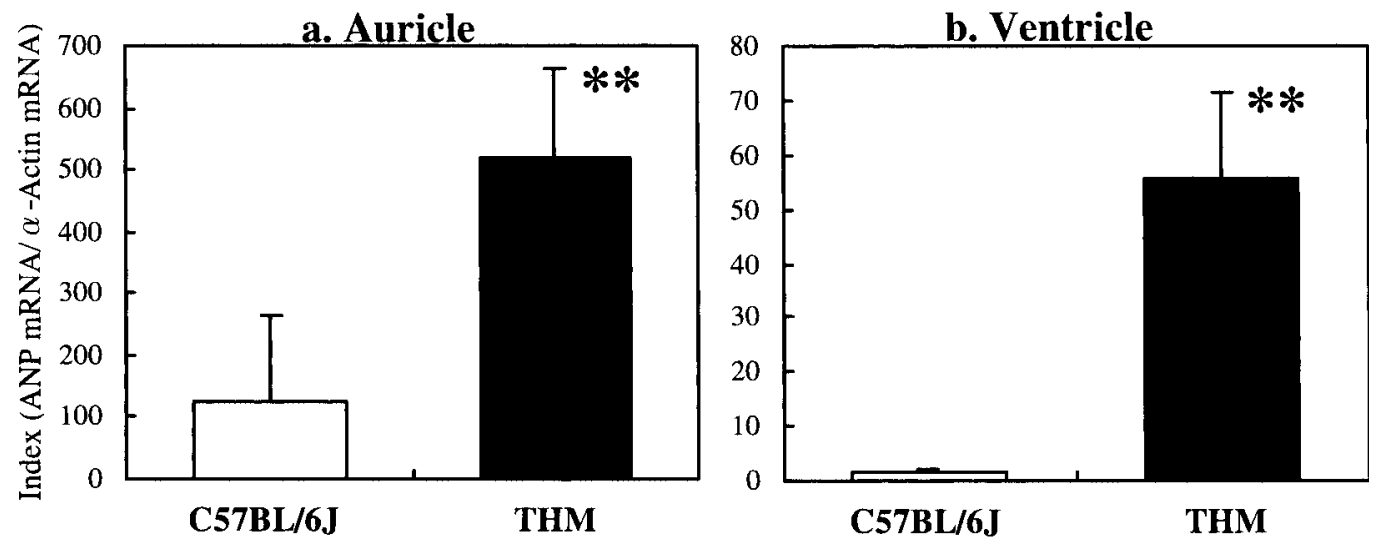

Fig. 4. ANP mRNA levels of the right auricle (a) and the left ventricle (b) in THM ( $n=5)$ and C57BL/6J mice $(\mathrm{n}=5)$. Data are mean \pm standard deviation. ** Significant difference $(\mathrm{p}<0.001)$.

that in the normotensive mice as well as the level of ventricular ANP mRNA. These findings suggest that the biosynthesis of ANP in the auricular and ventricular cardiocytes was augmented in THM. Usually, in the adult mammalian ventricle, ANP is synthesized only in the impulse-conducting system [27, 28, 42]. Biochemical research has shown that ventricular myocytes in a physiologically-intact condition contain little ANP [14]. It has also been reported that fetal and perinatal ventricles possess ANP and ANP mRNA though in the postnatal period their concentrations rapidly decrease $[4,41]$. With the expression of ANP in the fetus and its decrease in the adult, this peptide may contribute to the developmental control of cardiac myocytes. Although the mRNA of ANP is expressed in normal ventricular myocytes, the ANP-granules were not found in the working myocytes [4]. In constitutive secretion, secretory products are hard to find in electron micrographs of the cytoplasm. If proteins are secreted as fast as they are synthesized, then this would suggest that ventricular ANP is rapidly released by a 'constitutive pathway' [20]. Also, it has been reported that ventricular ANP is mainly released by a constitutive pathway in hypertensive animal models (SHR and SHRSP), suggesting that ventricular ANP contributes to elevation of the plasma ANP level in hypertension [2, 31]. Although we could not confirm whether or not the ANP-like granules of the ventricular cardiocytes found only in THM contained ANP products, our results along with the proposition by Kelly [20] raise the possibility that ANP is more rapidly secreted from the ventricle by a constitutive pathway in THM than in normotensive mice. In support of this we note that the ventricular ANP mRNA level in THM was approximately 40-fold higher than that in normotensive mice, and corresponded with an increase in ventricular ANP concentration. ANP is also synthesized in the working myocytes in the ventricle of a hypertensive heart $[2,31]$, a heart with hypertrophic cardiomyopathy $[33,38]$ and in heart failure [43] as the urgent circulating hormone. The manner of the secretion of ANP in the diseased heart may be associated with some augmented biosynthesis of ANP in the ventricular cardiocytes. It is possible that the hypertrophic process of the ventricle induced by hypertension in THM may contribute to the increased expression of ANP.

ANP in the atrium was reported to increase following salt repletion after drinking $1 \% \mathrm{NaCl}$ solution [40], and to decrease in the deoxycorticosterone acetate (DOCA)-salt-hypertensive rat [36]. ANP release may increase with salt repletion, which may indicate an increased demand for ANP. At the same time, biosynthesis of ANP increases in response to the demand for ANP, which favors an increase in atrial storage of ANP in a salt-repleted rat [40]. In the case of the DOCA-salt hypertensive rat, decreased atrial storage may be due to an increase in ANP release [36]. Ackermann and Irizawa [1] found that fucose uptake into the atrium, a possible indicator of the rate of formation of atrial ANP-granules, was more rapid in the DOCA-salt treated rat than in the sodium-deficient rat, suggesting that the turnover of secretory granules may 
have increased. Hence, it is conceivable that the atrial content of ANP changes according to the degree of release and biosynthesis of ANP. It is likely that the decreased ANP-granules, despite the increased ANPimmunoreactivity shown by RIA and the increased ANP mRNA level in the THM auricle shown in the present study, resulted from the increase in ANP release, and that the turnover of auricular ANP-granules in THM was higher than that in the normotensive mouse. ANP in the auricle is believed to be a hormone with vasodilating and natriuretic activities which is stored in secretory granules and is secreted by a 'regulated pathway'. In this pathway newly synthesized proteins destined for secretion are stored at high concentrations in secretory granules until the cell receives an appropriate stimulus [20], such as distension in the atrial wall [15]. As the present study showed that ANP was more rapidly secreted from the ventricle by a constitutive pathway in THM than in the normotensive mouse without the existence of ANP-granules in the ventricular cardiocytes, we propose that ANP may be secreted from the atrium by both regulated and constitutive pathways as responses to the demand for more plasma ANP in THM, and that ANP in the auricular cardiocytes may be stored as secretory granules rather than widely distributed in the cytoplasm of the THM cardiocytes. However, further studies are needed to clarify whether ANP secretion from the auricle is regulated and/or constitutive under pathophysiological conditions, especially in hypertension.

The present study showed that the plasma cyclic GMP level was the same in both THM and the normotensive mouse despite higher levels of heart and plasma ANP in THM than in the normotensive mouse. Several lines of evidence support the concept that ANP activates particulate guanylate cyclase and increases cyclic GMP accumulation in numerous cell types and tissues, including the vascular smooth muscle, endothelial cells, fibroblasts, and renal cells [44]. In the human and rat, an intravenous administration of ANP has been reported to elevate the plasma cGMP level $[16,18]$. Together, these findings suggest the significance of cyclic GMP as a second messenger and biological marker of ANP. Although the coupling of cyclic GMP increment with vasodilation by ANP has not been fully explained, the plasma cyclic GMP level could reflect vasodilating activity by ANP $[16,30]$. Thus, the suppression of the enhanced plasma cyclic GMP level by augmented ANP synthesis and ANP release in the heart tissues might inhibit the vasodilating action of endogenous ANP at its enhanced level, resulting in the aggravation of hypertension in THM. It remains to be determined whether suppression in the activity of cyclic GMP in THM is ascribed to an etiological role, or a compensatory mechanism in the induction of essential hypertension.

It is well known that there is a cross-regulation between the cardiac RAS and ANP systems [9]. Under pathological condition, angiotensinogen and ANP are found in the atrial muscle, the conduction system, and in the subendocardial layer of the left ventricle of human heart [35]. At the molecular level, angiotensin II stimulates ANP synthesis and release in neonatal rat myocytes [24], and ANP regulates renin and angiotensinogen mRNA levels in neonatal cardiac fibroblasts [23]. Further, activation of the cyclic GMP-coupled receptor is associated with upregulation of renin and angiotensinogen mRNA expression [23]. In THM, the existence of the chimeric RAS in addition to endogenous murine RAS results in the overproduction of angiotensin I and II [12]. Consequently, our findings suggest that ANP synthesis and release in heart tissues were stimulated by cross-regulation between the cardiac ANP system and RAS (including the chimeric RAS) in THM. However, we could not determine whether the stimulation was caused by the combination of RAS and chimeric RAS, or solely due to the physiological interaction between the products of the two introduced human renin and angitensinogen genes in THM.

In conclusion, our present data showing heart and plasma ANP increases in THM suggest a compensatory increase in biosynthesis and release in correlation with the hypertension induced by RAS. Thus, cardiac ANP synthesis and release may be involved in cross-regulation between the ANP circulating system and RAS.

\section{References}

1. Ackermann, U. and Irizawa, T. G. 1984. Synthesis and renal activity of rat atrial granules depend on extracellular volume. Am. J. Physiol. 247: R750-R752.

2. Arai, H., Nakao, K., Saito, Y., Morii, N., Sugawara, A., Yamada, T., Itoh, H., Shiono, S., Mukoyama, M., Ohkubo, H., Nakanishi, S., and Imura, H. 1988. Augmented 
expression of atrial natriuretic polypeptide (ANP) gene in ventricles of spontaneously hypertensive rats (SHR) and SHR-stroke prone. Circ. Res. 62: 926-930.

3. Arai, H., Nakao, K., Saito, Y., Morii, N., Sugawara, A., Yamada, T., Itoh, H., Shiono, S., Mukoyama, M., Ohkubo, H., Nakanishi, S., and Imura, H. 1987. Simultaneous measurement of atrial natriuretic polypeptide (ANP) messenger RNA and ANP in rat heart. Evidence for a preferentially increased synthesis and secretrion of ANP in left atrium of spontaneously hypertensive rats (SHR). Biochem. Biophys. Res. Commun. 148: 239-245.

4. Bloch, K. D., Seidman, J. G., Naftilan, J. D., Fallon, J. T., and Seidman, C. E. 1986. Neonatal atria and ventricles secreate atrial natriuretic factors via tissue-specific secretory pathways. Cell 47: 695-702.

5. Cantin, M. and Genest, J. 1985. The heart and the atrial natriuretic factor. Endocr. Rev. 6: 107-127.

6. Cantin, M., Timm-Kennedy, M., El-Khatib, E., Huet, M., and Yunge, L. 1979. Ultrastructural cytochemistry of atrial muscle cells: Comparative study of specific granules in right and left atrium of various animal species. Anat. Rec. 193: 55-70.

7. de Bold, A. J. 1979. Heart atria granularity effects of changes in water electrolyte balance. Proc. Soc. Exp. Biol. Med. 161: 508-511.

8. de Bold, A. J., Borenstein, H. B., Veress, A. T., and Sonnenberg, H. 1981. A rapid and potent natriuretic response to intravenous injection of atrial myocardial extracts in rats. Life Sci. 28: 89-94.

9. Dostal, D. E. and Baker, K. M. 1999. The cardiac reninangiotensin system: Conceptual, or regulator of cardiac function? Circ. Res. 85: 643-650.

10. Frolich, E. D. 1991. The heart in hypertension: A 1991 overview. Hypertension 18; 62-68.

11. Fukamizu, A., Seo, M.-S., Hatae, T., Yokoyama, M., Nomura, T., Katsuki, M., and Murakami, K. 1989. Tissuespecific expression of the human renin gene in transgenic mice. Biochem. Biophys. Res. Commun. 165: 826-832.

12. Fukamizu, A., Sugimura, K., Takimoto, E., Sugiyama, F., Seo, M.-S., Takahashi, S., Hatae, T., Kajiwara, N., Yagami, K., and Murakami, K. 1993. Chimeric renin-angiotensin system demonstrates sustained increase in blood pressure of transgenic mice carrying both human renin and human angiotensinogen genes. J. Biol. Chem. 268: 11617-11621.

13. Garcia, R., Cantin, M., Thibault, G., Ong, H., and Genest, J. 1982. Relationship of specific granules to the natriuretic and diuretic activity of rat atria. Experientia 38: 10711073.

14. Gardner, D. G., Deschepper, C. F., Ganong, W. F., Hane, S., Fiddes, J., Baxter, J. D., and Lewicki, J. 1986. Extraatrial expression of the gene for atrial natriuretic factor. Proc. Nat. Acad. Sci. USA 83: 6697-6701.

15. Go, J. and Gonzalez-Levin, L. 1988. Light and electron microscopic localization of atrial natriuretic peptide in the heart of spontaneously hypertensive rat. J. Histochem. Cytochem. 36: 1239-1249.

16. Hamet, P., Tremblay, J., Pang, S. C., Skuherska, R., Schiffrin, E. L., Garcia, R., Cantin, M., Genest, J., Palmour,
R., Erwin, F. R., Martin, S., and Goldwater, R. 1986. Cyclic GMP as mediator and biological marker of atrial natriuretic factor. J. Hypertens. 4 (Suppl. 2): S49-S56.

17. Itoh, H., Nakao, K., Katsuura, G., Morii, N., Shiono, S., Sakamoto, M., Sugawara, A., Yamada, T., Saito, Y., Matsushita, A., and Imura, H. 1986. Centrally infused atrial natriuretic polypeptide attenuates exaggerated salt appetite in spontaneousely hypertensive rats. Circ. Res. 59: 342347.

18. Itoh, H., Nakao, K., Mukoyama, M., Yamada, T., Hosoda, K., Shirakami, G., Morii, N., Sugawara, A., Saito, Y., Shiono, S., Arai, H., Yoshida, I., and Imura, H. 1989. Chronic blockade of endogenous atrial natriuretic polypeptide (ANP) by monoclonal antibody against ANP accelerates the development of hypertension in spontaneously hypertensive and deoxycorticosterone acetate-salt-hypertensive rats. J. Clin. Invest. 84: 145-154.

19. Imada, T., Takayanagi, R., and Inagami, T. 1985. Changes in the content of atrial natriuretic factor with the progression of hypertension in spontaneously hypertensive rats. Biochem. Biophys. Res. Commun. 133: 759-765.

20. Kelly, R. B. 1985. Pathway of protein secretion in eukaryotes. Science 230: 25-32.

21. Laragh, J. H. and Brenner, B. M. 1990. Hypertension: Pathophysiology, Diagnosis, and Management, vol. 1, Raven Press, New York.

22. Li, Y., Kishimoto, I., Saito, Y., Harada, M., Kuwahara, K., Izumi, T., Takahashi, N., Kawakami, R., Tanimoto, K., Nakagawa, Y., Nakanishi, M., Adachi, Y., Garbers, D.L., Fukamizu, A., and Nakao, K. 2002. Guanylyl cyclase-A inhibits angiotensin II type $1 \mathrm{~A}$ receptor-mediated cardiac remodeling, an endogenous protective mechanism in the heart. Circulation 106: 1722-1728.

23. Lin, C. L., Baker, K. M., Rothblum, K. C., Booz, G. W., and Dostal, D. E. 1995. Atrial natriuretic peptide regulation of renin and angiotensinogen mRNA in cultured neonatal rat ventricular cardiac fibroblasts. Hypertension 26: A563.

24. Matsubara, H., Hirata, Y., Yoshima, S., Takata, S., Takagi, Y., Yamane, Y., and Inada, M. 1988. Role of calcium and protein kinase $\mathrm{C}$ in ANP secretion by cultured rat cardiomyocytes. Am. J. Physiol. 24: H405-H409.

25. Matsubara, H., Nishikawa, M., Umeda, Y., Taniguchi, T., Iwasaka, T., Kurimoto, T., Yamane, Y., and Inada, M. 1987. The role of atrial pressure in secretory atrial natriuretic polypeptides. Am. Heart J. 133: 1457-1463.

26. Mifune, H., Suzuki, S., Noda, Y., Hayashi, Y., and Mochizuki, K. 1991a. Atrial natriuretic peptide (ANP)granules of the auricular cardiocytes in syrian hamsters during the pre- and postnatal growth period. Acta. Histochem. Cytochem. 24: 613-618.

27. Mifune, H., Suzuki, S., Noda, Y., Mohri, S., and Mochizuki, K. 1991b. Fine structure of atrial natriuretic peptide (ANP)granules in the atrial cardiocytes in mouse, rat and mongolian Gerbil. Exp. Anim. 40: 183-193.

28. Mifune, H., Suzuki, S., Noda, Y., Mohri, S., and Mochizuki, K. 1991c. Fine Structure of Atrial Natriuretic Peptide (ANP)-granules in the Atrial Cardiocytes in the Pig, Cattle and Horse. J. Vet. Med. Sci. 53: 561-568. 
29. Morii, N., Nakao, K., Kihara, M., Sugawara, A., Sakamoto, M., Yamori, Y., and Imura, H. 1986. Decreased content in left atrium and increased plasma concentration of atrial natriuretic polypeptide in spontaneously hypertensive rats (SHR) and SHR stroke-prone. Biochem. Biophys. Res. Commun. 135: 74-81.

30. Murad, F., Leitman, D.C., Bennett, B.M., Molina, C., and Waldman, S.A. 1987. Regulation of guanylate cyclase by atrial natriuretic factor and role of cyclic GMP in vasodilation. Am. J. Med. Sci. 294: 139-143.

31. Nishimura, T., Mizukawa, K., Nakao, K., Yamada, H., Kinoshita, M., and Ochi, J. 1994. Atrial natriuretic polypeptide (ANP)-immunoreactivity and specific atrial granules in cardiac myocytes of stroke-prone spontaneously hypertensive rat (SHRSP). Arch. Histol. Cytol. 57: 1-7.

32. Nokihara, K. and Hellstern, H. 1990. Synthesis of human cardiodilatin related peptides by fragment assembly on a polymer support. pp. 7-10. In: Peptide Chemistry (Yanaihara, N. ed.), Protein Research Foundation, Osaka.

33. Saito, Y., Nakao, K., Arai, H., Sugawara, A., Morii, N., Yamada, T., Itoh, H., Shiono, S., Mukoyama, M., Obata, K., Yasue, H., Ohkubo, H., Nakanishi, S., and Imura, H. 1987. Atrial natriuretic polypetide (ANP) in human ventricle increased gene expression of ANP in dilated cardiomyopathy. Biochem. Biophys. Res. Commun. 148: 211-217.

34. Sakamoto, M., Nakao, K., Sugawara, A., Morii, N., Saito, Y., Itoh, H., Yamada, T., Shiono, S., Shimokura, M., Kiso, Y., Kihara, M., Yamori, Y., and Imura, H. 1986. Effect of DOCA and salt loading on atrial and plasma levels of atrial natriuretic polypeptide. pp 373-378. In: Peptide Chemistry (Kiso, Y. ed.), Protein Research Foundation, Osaka.

35. Sawa, H., Kawaguchi, H., Mochizuki, N., Endo, Y., Kudo, T., Tokuchi, F., Fujioka, Y., Nagashima, K., and Kitabatake, A. 1994. Distribution of angiotensinogen in diseased human hearts. Mol. Cell Biochem. 132: 15-23.

36. Sugimoto, T., Ishii, M., Hirata, Y., Matsumoto, H., Sugimoto, T., Miyata, A., Toshimori, T., Masuda, H., Kangawa, K., and Matsuo, H. 1986. Increased release of atrial natriuretic polypeptides in rat with DOCA-salt hypertension. Life Sci. 38: 1351-1358.

37. Takahashi, S., Fukamizu, A., Hasegawa, T., Yokoyama, M., Nomura, T., Katsuki, M., and Murakami, K. 1991. Expression of the human angiotensinogen gene in transgenic mice and transfected cells. Biochem. Biophys. Res. Commun. 180: 1103-1109.

38. Takemura, G., Fujiwara, H., Mukoyama, M., Saito, Y., Nakao, K., Kawamura, A., Ishida, M., Kida, M., Uegaito, T., Tanaka, M., Matsumori, A., Fujiwara, T., Imura, H., and Kawai, C. 1991. Expression and distribution of atrial natriuretic peptide in human hypertrophic ventricle of hypertensive hearts and hearts with hypertrophic cardiomyopathy. Circulation 83: 181-190.

39. Tanaka, I. and Inagami, T. 1986. Increased concentration of plasma immunoreactive atrial natriuretic factor in Dahl salt sensitive rats with sodium chloride-induced hypertension. J. Hypertens. 4: 109-112.

40. Tanaka, I., Misono, K. S., and Inagami, T. 1984. Atrial natriuretic factor in rat hypothalamus, atria and plasma: Determination by specific radioimmunoassay. Biochem. Biophys. Res. Commun. 124: 663-668.

41. Toshimori, H., Toshimori, K., Oura, C., and Matsuo, H. 1987a. Immunohistochemical study of atrial natriuretic polypeptide in the embryonic, fetal and neonatal rat heart. Cell Tiss. Res. 248: 627-633.

42. Toshimori, H., Toshimori, K., Oura, C., and Matsuo, H. 1987b. Immunohistochemistry and immunocytochemistry of atrial natriuretic polypeptide in porcine heart. Histochemistry 86: 595-601.

43. Tsutamoto, T., Bito, K., and Kinoshita, M. 1989. Plasma atrial natriuretic polypeptide as an index of left ventricular end-diastolic pressure in patients with chronic left-sided heart failure. Am. Heart J. 117: 599-606.

44. Waldman, S. A., Rapoport, R., and Murad, F. 1984. Atrial natriuretic factor selectively activates particulate guanylate cyclase and elevates cyclic GMP in rat tissues. J. Biol. Chem. 259: 14332-14334. 